\title{
Model Penciptaan Karya Lagu Anak Populer yang Berangkat dari Nilai Tradisi
}

\author{
Catur Surya Permana \\ Program Studi Seni Musik, Fakultas Ilmu Seni dan Sastra, Universitas Pasundan, Bandung \\ Telp.+6285220009116; email: Cataursurya35@gmail
}

Ridwan Sigit

Program Studi Ekonomi, Fakultas Ekonomi, Universitas Pasundan, Bandung

Telp. +6285220009116; email: Cataursurya35@gmail

\begin{abstract}
The purpose of this study is to get a good shape in making musical works for children in particular raised the value of tradition, so that the output to be achieved by researchers for academic students, especially music students are able to create or conceptualize a work of music for children, which will help students and other academic people compete in the music industry globally. By using the method of qualitative analysis with approaches on musicology, with the theory of Form Analysis, Harmony, composition and literataure about the value of the tradition, then from the foundation is obtained by analyzing the work of children's songs obtained directly from the source of cassette recordings or audio-visual, literataure, and direct application that closely related to the research. Expected results get patterns of musical forms, lyrics, melodies, and chords that are able to describe or characterize a child's pop music that represents the value of tradition.
\end{abstract}

Keywords: Analysis; creation of children's songs; musical forms; traditional values.

\begin{abstract}
Abstrak
Tujuan penelitian ini adalah untuk mendapatkan bagaimana bentuk yang baik dalam membuat karya musik untuk anak khususnya mengangkat nilai tradisi, sehingga luaran yang ingin dicapai peneliti agar insan akademis khususnya mahasiswa seni musik mampu untuk membuat ataupun mengonsep sebuah karya musik untuk anak, yang nantinya akan membantu mahasiswa dan insan akademis lainnya untuk bersaing dalam industri musik secara global. Menggunakan metode analisis kualitatif dengan pendekatan pada musikologi, dengan teori Ilmu Bentuk Analisis, Harmoni, komposisi dan litelataur mengenai nilai tradisi ke'Sunda'an, maka dari dasar tersebut dapat diperoleh dengan cara menganalisis karya lagu anak yang didapat langsung dari sumber yaitu rekaman kaset ataupun audiovisualnya, literataur, serta pengaplikasian secara langsung yang erat kaitannya dengan penelitian. Hasil yang diharapkan mendapatkan pola-pola bentuk musik, lirik, melodi, serta akor yang mampu menggambarkan atau mencirikan sebuah karya musik pop anak yang merepresentasikan nilai tradisi.
\end{abstract}

Kata kunci: analisis, penciptaan lagu anak, bentuk musik, nilai tradisi

\section{Pengantar}

Perkembangan musik anak di tahun 2016 ini sangat kurang sekali, belum lagi kurangnya lagu anak yang dapat di ekspose media untuk diapresiasi. Lagu anak biasanya hanya ditemui dan dilakukan di sekolahsekolah tingkat dasar. Padahal kelanjutannya haruslah juga diperhatikan sebagai wujud tanggung jawab kita terhadap perkembangan generasi penerus bangsa.

Sebetulnya permasalahan ini sudah coba diangkat dan dibangkitkan oleh acara PPKI, Festival Lagu Anak (Fesla) di tahun 2013. Acara tersebut dihadiri oleh ibu Mari Elka Pangestu, dan sejumlah pejabat negara di bidang Parekraf. Ibu Mari menuturkan 
bahwa: "Perkembangan Musik Anak Indonesia saat ini sangat mengkhawatirkan. Lagu-lagu yang tidak pantas dinyanyikan anak-anak malah dinyanyikan. Lagu anak yang mendidik seperti di tahun 80 -an sudah tidak ada lagi". Artinya kehadiran musik anak menjadi sangat kritis keberadaanya.

Terlebih lagi hingga tahun inipun hasil dari diselenggarakannya acara tersebut nampaknya belum menghasilkan suatu hal yang konkrit. Artinya hingga tahun 2015pun musik anak masih dalam keadaan yang kritis, dan kurang mendidik. Hal ini padahal sudah menjadi kewajiban kita bersama, baik para akademis, dan juga pemerintah untuk ambil andil dalam perkembangannya.

Belum banyaknya tulisan-tulisan mengenai bentuk musik anak, yang bisa mewakili secara representatif dalam membedah isi dan bentuk musik lagu-lagu anak. Yang biasanya ditemukan hanya kumpulan-kumpulan lagu anak, akor-akor iringan lagu anak, dan lirik-liriknya. Untuk itu maka pengayaan bahan ajar maupun model-model konsep cipta karya musik harus dibentuk, dibuat, dan dikerjakan oleh para peneliti, agar pengetahuan mengenai musik anak dapat diketahui secara eksplisit dan mendalam.

Selain itu, lagu-lagu anak yang menjadi sorotan peneliti, berkisar pada lagu-lagu yang datangnya dari era 90 -an. Kita ingat masa kejayaan lagu anak, seperti Di tahun 1990-an ada Kuku-Kuku (Chiquitta Meidy), Diobok-Obok (Joshua), Senyum Naka" (Enno Lerian), Jangan Marah (Trio Kwek Kwek), sampai Bolo-Bolo (Tina Toon). Lagu-lagu seperti itu yang sangat menggema ditelinga kita, dan sangat momentual, romantisasi lagu-lagu anak, bila kita dengar, kembali masa-masa dahulu. Lagu anak populer sebetulnya sudah dimulai dari sejak tahun 70an antara lain ada Eh Copot Copot (Adi Bing Slamet) dan Helly (Chicha Koeswoyo) dan di tahun 80-an seperti lagu ada Mama (Puput
Novel), Balada Anak Nelayan (Julius Sitanggang), Satu Ditambah Satu (Puput Melati), dan Abang Tukang Bakso (Melissa).

Begitu banyaknya lagu anak yang bisa dihasilkan, berbeda dengan tahun ini yang hanya menghasilkan lagu Malu sama kucing oleh penyanyi Romaria. Masalahnya lagu-lagu anak ini kalah me-"massa"nya dengan lagu dewasa. Kurangnya juga ruang untuk kreativitas anak untuk dapat unjuk gigi ditelevisi ataupun media-media siar yang ada. Segmentasi anak memang jauh dengan segmentasi remaja juga dewasa, namun keseimbangan juga harus diperhatikan.

Penyanyi serta ruang publik, dapat menunjukkan musik anak hidup dan eksis, tetapi perlu juga kita perhatikan para penciptanya, dalam arti pencipta lagu anak. Kita dapat saksikan bersama bahwa masa kini musik anak tidak lagi memiliki tokoh yang dianuti oleh masyarakat sebagai pencipta lagu anak. Dulu kita kenal beberapa tokoh yang sangat dikenal sebagai pencipta lagu anak antara lain, Bu Kasur, Ibu dan Bapak Soed, A.T. Mahmud serta Papa T.Bob. Selain nama-nama tersebut, kini jarang sekali terdengar nama atau pencipta lagu anak seharum nama-nama itu.

Hal lainnya yang menyangkut musik dan lagu anak adalah perihal keterkaitannya dengan nilai-nilai yang dikandung. Perlu kita ketahui bahwa lagu yang memiliki landasan lirik yang kuat, akan diterima masyarakat dan disenandungkan. Lirik tersebut hadir sebagai wujud dari nilai-nilai yang tersirat dalam sajian verbal yang dapat ditangkap dengan mudah. Nilai tersebut dapat memberi nilai negatif ataupun positif.

Perhatian lainnya yang dirasakan penulis yaitu pada sisi nilai tradisi dalam lagu anak. Tidak banyak lagu anak yang merepresentasikan nilai tradisi. Mengapa itu penting? nilai merupakan suatu hal yang kita anggap berharga dan tidak dapat diwujudkan namun diakui sebagai benda bernilai (value). Di satu sisi juga dalam tradisi 
kita memiliki suatu hal yang layak kita apresiasi dan lestarikan keberadaannya. Arus globalisasi membawa kita ke dalam lonjakan tajam untuk menerima perubahan besar dalam cara berpikir, cara hidup, dan cara pandang kita. Kekerasan, tindak kriminal, saling memaki, saling menjatauhkan, dan sebagainya itu merusak bangsa. Oleh sebab arus tersebut yang memukul habis puingpuing nilai tradisi yang kita miliki. Nilai dalam tradisi kita harusnya mampu membawa ke dalam kehidupan yang adil, makmur, selaras, serasi dan seimbang, karena di dalam nilai tradisi tersebut terdapat identitas kita sebagai bangsa yang memiliki moral yang baik. Model penciptaan lagu anak ini perlu juga memiliki nilai tradisi, agar ketika anak menyanyikan dan mendengar lagu tersebut dapat terus tetap menjaga kelestarian, moral, serta identitas kita sebagai bangsa Indonesia.

\section{Pembahasan}

\section{Nilai Tradisi Budaya Sunda}

Sunda merupakan salah satu suku yang ada di Indonesia yang berasal dari Jawa Barat. Sebagai suatu bentuk kultur yang ada dalam kesatuan tanah air, tidak lepas kiranya bahwa Sunda memiliki adat, kesenian, religiusitas, cara bertani, atauran yang masuk dalam unsur kebudayaan. Masyarakat Sunda dikenal berwatak lemah-lembut, sopan, halus, berjiwa satria, sangat menenggang rasa orang lain (Rosidi, 2009:192). Sebenarnya yang dianggap sebagai nilai dalam suatu budaya adalah bukan mempermasalahkan mengenai angka, melainkan mengenai value. Nilai value yang dimaksud adalah nilai berharganya sesuatu atas dasar mempunyai nilai lebih dari ketimbang fungsi atau bentuk barang itu sendiri. Oleh karena itu yang dimaksud sebagai nilai tradisi adalah sesuatu yang berharga yang ada dalam tradisi/ kebiasaan masyarakat Sunda. Kebiasaan yang baik tersebutlah yang akan dibangun nantinya kedalam konstruksi sebuah karya.
Masyarakat Sunda sendiri memiliki elemen-elemen yang diciptakannya yang termasuk dalam unsur kebudayaan tadi. Dalam Sunda dikenal adanya bahasa Sunda, kesenian Sunda, cara pemerintahan Sunda, cara Sunda dalam memperhatikan religiusitas. Dalam kesenian musik Sunda terdapat elemen-elemen yang membentuknya, mulai dari instrumen, struktur harmoni, nada, melodi, lirik dan lainnya. Hal seperti ini yang nantinya akan digubah dalam sebuah karya, ataupun dapat berupa sebuah konstruk garap lagu anak yang berdasar idiom-idiom Sunda.

Anggapan bahwa budaya lokal yang menjadi sumber budaya didik akan mampu mengimbangi imbas pengaruh serbuan budaya global, diharapkan dengan mengacu pada nilai-nilai tradisi budaya, akan dapat memberi nilai kebaikkan dan pendidikan musik yang berbasis budaya lokal, sehingga nilai tradisi tersebut tidak akan terkikis dengan arus global.

\section{a. Tinjauan Teoritis Nilai}

Nilai merupakan suatu kata yang menggambarkan kedalaman. Kedalaman tersebut juga berupa suatu pandangan dari manusia atau subjek. Nilai sendiri tidak bisa hidup sendiri, melainkan dihidupi oleh subjek. Subjeklah yang menamai dan memberi nilai terhadap sesuatu yang dianggapnya bernilai. Seperti halnya suatu benda yang sama akan memiliki nilai yang berbeda dari kacamata setiap subjek yang berbeda juga. Kepemilikian nilai bisa menjadi sangat individual. Namun, berbeda dengan pandangan kolektif suatu masyarakat dalam memberi nilai. Hubungan suatu konteks masyarakat tertentu yang hidup dalam pandangan dan juga konsep nilainya tentu akan menghadirkan nilai yang juga memiliki pandangan kolektif. Sehingga nilai sendiri selain berbeda setiap subjek tapi juga memiliki kekolektifannya bila suatu itu dipandang dalam konteks masyarakat tertentu misalkan dalam etnis tertentu. 
Dari berbagai pendapat tentang nilai ini dapat dikemukakan sebuah batasan nilai (tentatif), yaitu: nilai adalah sesuatu yang dipentingkan manusia sebagai subjek, menyangkut segala sesuatu yang baik atau yang buruk sebagai abstraksi, pandanga, atau maksud dari pengalaman dengan seleksi perilaku yang ketat (Tim pengembangan Ilmu pendidikan, 2007:46).

Jadi nilai itu dapat dimengerti sebagai konsepsi yang dihayati seseorang (bisa juga kelompok) mengenai apa yang penting atau kurang penting, apa yang lebih baik atau kurang baik, apa yang lebih benar atau kurang benar (Gea, Antonina \&Yohanes, 2005:144). Nilai sendiri dapat diperoleh melalui beberapa kaitannya, antara lain:

1) Nilai berkaitan dengan fakta

2) Nilai berkaitan dengan subyek yang menilai

3) Nilai bersifat Praktis-pragmatis

4) Nilai secara potensial ada pada objek.

b. Makna Tradisi

Kebiasaan, masa lalu, sering terkait dengan istilah "tradisi". Tradisi sendiri bukan hanya berbicara mengenai hal yang lampau dalam kebiasaanya, namun juga hubungannya dengan nilai-nilai, norma, identitas, kebudayaan. Dalam upaya memenuhi hubungan tersebut manusia dengan segala kemampuannya menjadikan alam sebagai titik tolak pemenuhan kebutuhan tersebut. Manusia Hidup di alam yang besar yang dapat dipergunakannya sebagai media segala keperluan dan kepentingan manusia, misalnya saja kayu untuk membangun rumah, air sungai untuk mandi dan cuci, ladang untuk bercocok tanam, dan lain sebagainya. Kesemuanya itu tumbuh dalam alam pikir manusia menerjemahkan dunianya. Dunia yang ada mereka rekayasa agar menjadi berguna dan berfungsi. Itu merupakan wujud manusia dalam aktifitas hidupnya yang dapat menciptakan pola-pola hidup, tata cara, cara pandang, atauran, dan nilai-nilai yang mereka sepakati. Hal tersebut yang kemudian menciptakan bagaimana sebuah tradisi/ kebiasaan yang dilakukan oleh manusia dengan kelompoknya.

Tradisi adalah kesamaan benda material dan gagasan yang berasal dari masa lalu namun masih ada hingga kini dan belum dihancurkan atau dirusak (Maulana, 2014:25). Tradisi dapat diartikan Sebagai warisan yang benar atau warisan masa lalu. Namun demikian tradisi yang terjadi berulang-ulang bukanlah dilakukan secara kebetulan atau disengaja (Sztompka, 2007:69). Menurut Van Peursen (1988:11) tradisi diterjemahkan sebagai proses pewarisan atau penerusan norma-norma, adat istiadat, kaidah-kaidah, harta-harta. Penerusan tersebut dapat dirubah diangkat, ditolak dan dipadukan dengan ragam perbuatan manusia.

Menurut kebudayaan yang dikatakan Koentjaraningrat (Mattulada, 1997:1), mempunyai paling sedikit tiga wujud, yaitu:

1) Wujud kebudayaan sebagai suatu kompleks ide-ide, gagasan-gagasan, nilai-nilai, norma-norma, peratauran dan sebagainya.

2) Wujud kebudayaan sebagai kompleks aktivitas kelakuan berpola dari manusia dalam masyarakat.

3) Wujud kebudayaan sebagai bendabenda hasil karya manusia.

Berdasar hal tersebut di atas diyakinkan bahwa suatu kebudayaan itu memiliki konsep-konsep yang terstruktur yang mengataur tingkah bahkan pola manusia dalam segala wujud aktivitasnya, termasuk dalam penciptaan hasil karyanya. Artefak-artefak budaya termasuk artefak seni, baik itu tari, rupa, teater, dan musik merupakan suatu konsep berpikir manusia saat itu yang difungsikan sebagai sarana pengetahuan untuk memberi informasi mengenai apa yang terjadi pada masa dulu, agar di masa sekarang artefak tersebut kemudian digali dan ditanamkan kembali agar makna dan nilai dalam artefak itu dalam terus dipahami. 
Oleh sebab itu pada masyarakat yang memiliki kesamaan budaya, wilayah, dan berinteraksi dalam suatu hubungan sosial yang terstruktur tersebut, mewariskan masa lalunya melalui (Maulana, 2014:28):

1) Tradisi dan adat istiadat (nilai, norma yang mengataur perilaku dan hubungan antar individu dalam kelompok).

2) Nasehat dari para leluhur, dilestarikan dengan cara menjaga nasehat tersebut melalui ingatan kolektif anggota masyarakat dan kemudian disampaikan secara lisan turuntemurun dari satu generasi ke generasi selanjutnya.

3) Peranan orang yang dituakan (pemimpin kelompok yang memiliki kemampuan lebih dalam menaklukkan alam) dalam masyarakat.

4) Membuat suatu peringatan kepada semua anggota kelompok masyarakat berupa lukisan serta perkakas sebagai alat bantu hidup serta bangunan tugu atau makam.

5) Kepercayaan terhadap roh-roh serta arwah nenek moyang dapat termasuk sejarah lisan sebab meninggalkan bukti sejarah berupa benda-benda dan bangunan yang mereka buat.

Maka tradisi menyiratkan arti mengenai warisan, apa yang tersisa dari masa lalu. Yang senada dengan Shils (dalam Sztompka, 2007:70), yaitu keseluruhan benda material dan gagasan yang berasal dari masa lalu namun benar-benar masih ada kini, belum dihancurkan, dirusak, "tradisi berarti segala sesuatu yang disalurkan atau diwariskan dari masa lalu ke masa kini".

Adapun pengertian yang lain Tradisi (bahasa Latin: traditio, "diteruskan") atau kebiasaan, dalam pengertian yang paling sederhana adalah sesuatu yang telah dilakukan untuk sejak lama dan menjadi bagian dari kehidupan suatu kelompok masyarakat, biasanya dari suatu negara, kebudayaan, waktu, atau agama yang sama. Hal yang paling mendasar dari tradisi adalah adanya informasi yang diteruskan dari generasi ke generasi baik tertulis maupun (sering kali) lisan, karena tanpa adanya ini, suatu tradisi dapat punah.

Kekhasan masa lalu sebagai identitas, tidak hanya diam dalam aliran global. Sikap orientasi pikiran atau benda material atau gagasan yang berasal dari masa lalu yang dipungut orang dimasa kini. Artinya, kekhasan masa lampau tersebut akan mengalami perkembangan bentuk, pemaknaan kembali. Namun permasalahnnya apakah bentuk biramau tersebut akan menghilangkan keaslian nilai-nilainya atau tidak? Banyak sekali upaya yang dapat kita lakukan ke arah sana, namun tidak mudah karena terlanjur jalan yang sudah bertubitubi dan bergelombang. Untuk itu upaya menciptakan jalan panjang melestarikan nilai tradisi ini diharapkan dapat berlangsung lancar.

\section{Elemen Penting Penciptaan Lagu anak}

Hasil analisis terhadap wujud lagu anak terdapat beberapa hal yang di anggap penting untuk diperhatikan, antara lain melodi, harmoni, dan tema lirik. Serta tiga hal tersebut dikaitkan dengan pola musik populer yang memiliki ciri keseragaman bentuk (simetris), dapat diikuti dengan mudah, range vokal mengikuti range anak, tema lirik yang sederhana dan mudah diingat, serta tidak lupa bahwa tema lirik yang diangkat harus sesuai dengan dunia anak, dan dapat juga merepresentasikan aktivitas kesehariannya.

Alasan tersebut mengapa lagu anak perlu diperhatikan, masalah bagaimana lagu tersebut diterima, layak-tidaknya, serta ada tidaknya faktor pendidikan di dalamnya. Konteks itu di anggap penting, karena sumber-sumber pembelajaran anak, menuju perkembangan mentalitas, fisik, pikiran, dan polah tingkah lakunya bisa disebabkan oleh keadaan yang juga tidak mendukung untuk 
terciptanya lagu anak. Lagu anak sendiri harus bersumber dari hal-hal yang positif dan berorientasi pada perkembangan anak, sehingga hal lain yang dianggap penting dalam penciptaan lagu anak adalah adanya faktor pendidikan, bagaimana anak menerima lagu tersebut, serta kelayakkan lagu tersebut dikonsumsi oleh anak.

Berikut hasil analisis bentuk lirik lagu anak yang diambil dari beberapa studi pada lagu Bintang Kecil (Pak Dal), Kasih Ibu (SM. Mochtar), Dua Mata Saya (Pak Kasur), Cicak di Dinding (AT. Mahmud), dan Burung Kutilang (Ibu Sud). Paparannya adalah sebagai berikut:

\section{Bintang Kecil}

Bintang Kecil di langit yang biru, Amat banyak menghias angkasa Aku ingin terbang dan menari, Jauh tinggi ke tempat kau berada

\section{Kasih Ibu}

Kasih Ibu kepada beta, tak terhingga sepanjang masa Hanya memberi tak harap kembali, bagai sang surya menyinari dunia

\section{Dua Mata Saya}

Dua Mata Saya hidung saya satu, Dua kaki saya pakai sepatau biramau Dua kuping saya yang kiri dan kanan Satu mulut saya tidak berhenti makan.

\section{Cicak di Dinding}

Cicak Cicak di Dinding,

diam-diam merayap

Datang seekor nyamuk

hap... lalu ditangkap

\section{Burung Kutilang}

Dipucuk pohon cemara, Burung Kutilang berbunyi

Bersiul-siul sepanjang hari dengan tak jemu-jemu Mengangguk-angguk sambil bernyanyi trilili lili li lilili
Berdasar tema lirik di atas diketahui bahwa tema lirik yang digunakan merupakan deskripsi dari apa yang dilihat dan dirasakan, serta terdapat keinginan dan harapan sesuai dengan ciri musik anak yaitu berangkat dari dunia anak dan representasi aktivitas kesehariannya.

Hasil analisis musik secara umum meliputi aspek-aspek bentuk tema lagu, periode, frase, motif dan figur, secara khusus merupakan pembahasan melodi sebagai pokok dari bentuk lagu. Oleh sebab itu analisis dimulai dari bentuk musik yang dilihat dari melodi. Beberapa lagu yang dianalisis sebagai studi antara lain: Bintang Kecil (Pak Dal), Kasih Ibu (SM. Mochtar), Dua Mata Saya (Pak Kasur), Cicak di Dinding (AT. Mahmud), dan Burung Kutilang (Ibu Sud).

a) Bintang Kecil

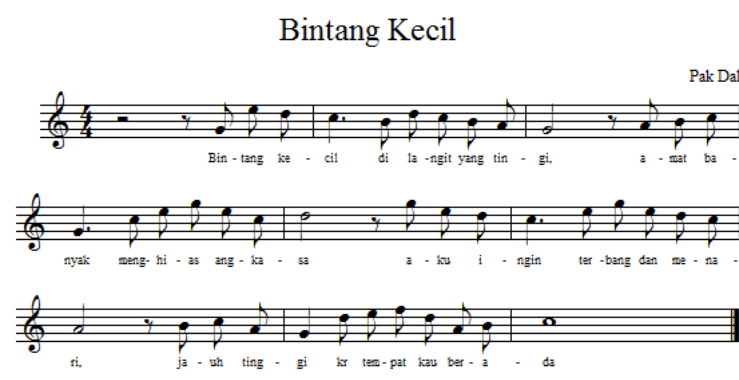

Ilustrasi 1.

Not balok lagu Bintang Kecil

Lagu ini memiliki frase tanya dan jawab dalam satu tema $\mathrm{A}(\mathrm{ax})$ periode yang tersusun dari 8 jumlah birama. Frase tanya dimulai dari birama pendahuluan (pickup bar) yang muncul sebelum birama 2 hingga birama 5 ketukan ke satu (a) dan di akhiri dengan akor V. Frase jawab dimulai dari birama 6 ketukan ketiga hingga $9(x)$ yang di akhiri oleh akor I.

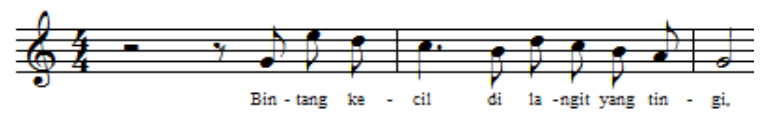

Ilustrasi 2.

Potongan motif dalam frase tanya lagu Bintang Kecil birama 2 hingga 3 
Motif melodi yang dibentuk dalam frase memiliki bentuk repetitif, dengan pengolahan motif frase menggunakan diminusi dan augmentasi baik dari segi nilai maupun nada. Untuk selanjutnya figur dari notasi, mayoritas menggunakan not $1 / 8$ (setengah ketuk). Progressi akor berputar pada akor mayor dalam tangga nada dengan progressi I-V-I, I-IV-I. Dengan tempo 83 bpm (moderato), maka memungkinkan notasi dimainkan dalam tempo sedang dan tidak terlalu cepat. Hal ini memudahkan anak bila menyanyi dalam penggalan-penggalan liriknya.

b) Kasih $\mathrm{Ibu}$

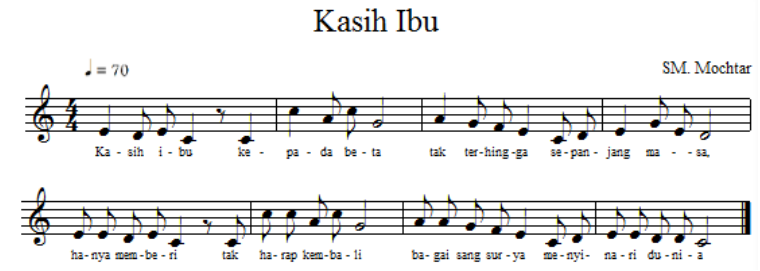

Ilustrasi 3.

Notasi balok lagu Kasih Ibu

Pengolahan motif ritmik yang digunakan dalam pengembangan melodi (augmentasi harga not dan variasi), seperti yang terlihat pada birama 1 hingga 2 dan bandingannya dengan birama 5 hingga 6 , serta pengembangan birama 3 hingga 4 dengan birama 7 hingga 8 .

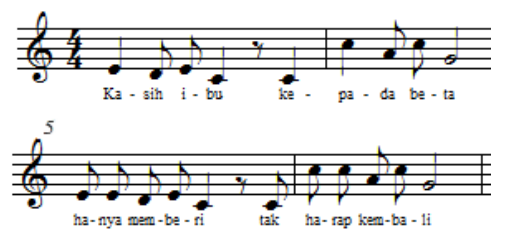

Ilustrasi 4.

Bentuk pengembangan motif pada birama 1-2 dengan 5-6 pada lagu Kasih Ibu

Lagu ini memiliki bentuk frase tanya dan jawab dalam satu tema $\mathrm{A}\left(\mathrm{aa}^{\prime}\right)$-- terlihat dari 8 jumlah birama/ simetris. Kalimat tanya dimulai dari birama 1 hingga 4 ketukan ke satu (a) dan di akhiri dengan akor $\mathrm{V}$, kalimat jawab birama 5 ketukan ke tiga hingga $8\left(a^{\prime}\right)$ yang di akhiri oleh akor I. Figur dari notasi mayoritas menggunakan not $1 / 8$ (setengah ketuk). Progressi akor yang berputar pada akor mayor dalam tangga nada dengan progressi I-V-I, I-IV-I. Tempo yang dipakai 70bpm (Adantino), tempo seperti ini lebih lambat dari lagu sebelumnya sehingga memungkinkan notasi yang dibunyikan tidak terlalu cepat, sehingga memudahkan anak bila menyanyi dalam penggalan-penggalan liriknya. Dan range/ interval antar nada melodi yang melangkah memudahkan anak untuk mencapai nada demi nada.

c) Dua Mata Saya

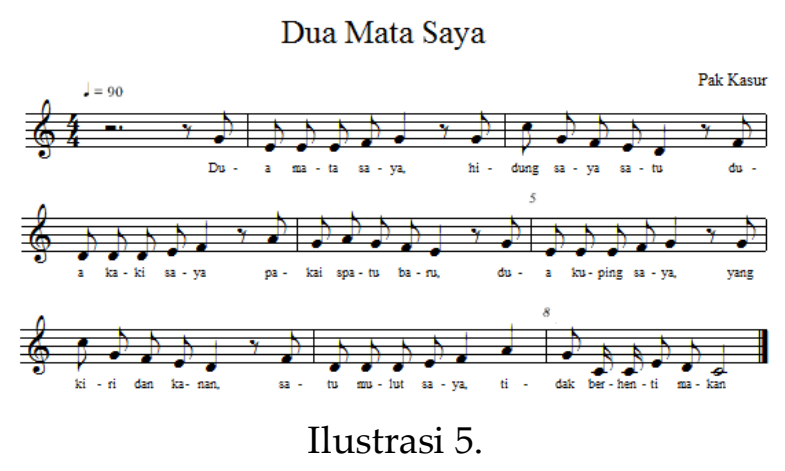

Notasi balok lagu Dua Mata Saya

Pengolahan motif yang repetitif nyaris di setiap birama, menunjukkan ringan dan sederhana lagu ini. Motif awal dari melodi ini (lihat ilustrasi 6) menghiasi keseluruhan lagu ini.

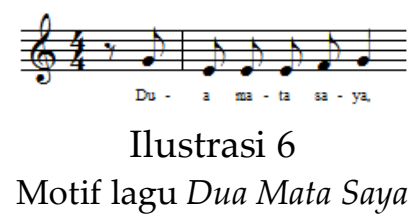

Lagu Dua Mata Saya memiliki bentuk frase tanya dan jawab dalam satu tema $\mathrm{A}\left(\mathrm{aa}^{\prime}\right)$ -- terlihat dari 8 (simetris) jumlah birama. Frase tanya dimulai dari birama 2 (termasuk satu nada gantung pada birama upbeat hingga birama 5 ketukan ketiga (a) dan diakhiri dengan akor I dengan nada mi (belum selesai). Frase jawab dari birama 6 ketukan ke empat hingga birama $9\left(a^{\prime}\right)$ yang di akhiri oleh akor I; variasi hanya tejadi pada birama terakhir (9). Figur dari notasi, mayoritas 
menggunakan not 1/8 (setengah ketuk). Progressi akor berputar pada akor mayor dalam tangga nada dengan progressi I-V-I, IIV-I. Tempo yang dipakai 90bpm (Allegretto); tempo seperti ini memang lebih tinggi dari kedua lagu di atas namun tetap memungkinkan notasi berjalan sedang dan tidak terlalu cepat, sehingga memudahkan anak bila menyanyi.

d) Cicak di Dinding

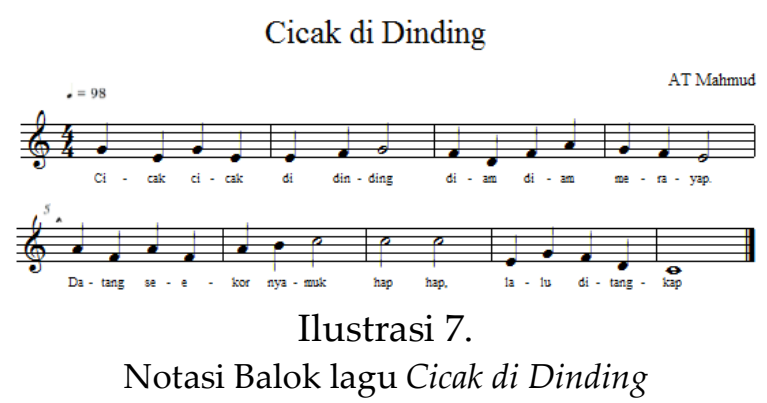

Antara birama 1-2 dengan birama 5-6 nampak jelas pengembangan motifnya menggunakan augmentasi notasi, sedang antara birama 3-4 dengan birama 8-9 terjadi pengembangan motif dengan teknik inversi. Lagu ini lebih sederhana dengan kecepatan tempo 98bpm (Allegretto Mosso/Animato) dan menggunakan figur nada $1 / 4$ (satu ketuk); Lagu dewasa biasanya antara 100-120 untuk musik pop standarnya, tempo 140-160 biasanya digunakan untuk jenis musik rock, metal, dan underground.

Lagu ini memiliki bentuk frase tanya dan jawab dalam satu tema A(ax) sebagaimana terlihat dari jumlah 9 (tampak seakan asimetris) birama. Frase tanya dimulai dari birama 1 hingga 4 (a) dan di akhiri dengan akor I ( $m i-$ belum selesai). Frase jawab dari birama 5 hingga 9 (x) yang di akhiri oleh akor I. Progres akor yang digunakan antara lain I-V-I, kemudian IV-I-V-I.

Frase kedua berjumlah 5 birama sehingga menimbulkan dugaan adanya penggunaan periode asimetris. Namun demikian mengapa masih mudah dinyanyikan oleh anak-anak sebagaimana laiknya periode yang simetris. Jika demikian pasti ada penyebabnya mengapa frase jawab lebih panjang dari frase tanya. Dalam kenyataanya pada frase jawab terdapat birama sisipan, yaitu pada birama ke-7 yang terisi oleh dua nada setengah dengan lirik: hap, hap. Dengan demikian birama ketujuh inilah yang menjadi sebab adanya perluasan pada frase jawab. Jika birama ini dihilangkan maka akan periode pada lagu ini akan berbunyi simetris sebagai sebuah periode yang normal.

\section{e) Burung Kutilang}

Lagu Burung Kutilang (lihat ilustrasi 8) termasuk unik, karena memiliki tema berlebih. Antara kalimat tanya dan jawabnya tidak simetris atau sedikit menyimpang (kalimat tanya sepanjang empat birama namun kalimat jawab sepanjang delapan birama). Biasanya terjadi untuk penegasan sesuatu.

Burung Kutilang

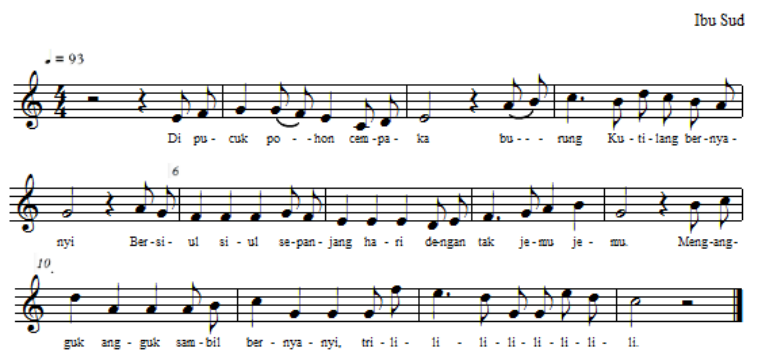

Ilustrasi 8.

Notasi Balok Lagu Burung Kutilang

Lagu Burung Kutilang termasuk unik, karena memiliki tema berlebih. Antara kalimat tanya dan jawabnya tidak simetris atau sedikit menyimpang (kalimat tanya sepanjang empat birama namun kalimat jawab sepanjang delapan birama). Biasanya terjadi untuk penegasan sesuatu.

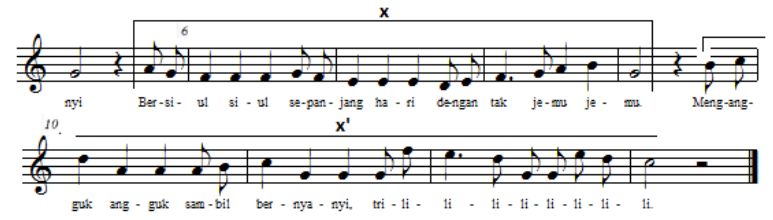

Ilustrasi 9 .

Potongan frase jawab x (birama 6-9) dan $x^{\prime}$ (birama 10-13) pada lagu Burung Kutilang. 
Lagu ini memiliki bentuk frase tanya dan jawab A(axx'). Frase tanya dimulai dari birama 2 hingga 5 ketukan ke satu (a) dan di akhiri dengan akor V. Frase jawab dari birama 6 ketukan ke empat hingga $9\left(a^{\prime}\right)$ yang di akhiri akor $\mathrm{V}$, kalimat jawab kedua dimulai dari birama 10 ketukan ke empat hingga 13 diakhiri dengan akor I.
Figur dari notasi, mayoritas menggunakan not $1 / 4$ (satu ketuk). Susunan akor berputar pada tanga nada mayor dengan progressi I-V-I, I-IV-I. Tempo yang dipakai 93bpm (Allegretto), tempo seperti ini tetap memungkinkan notasi berjalan sedang dan tidak terlalu cepat, sehingga memudahkan anak bila menyanyi.

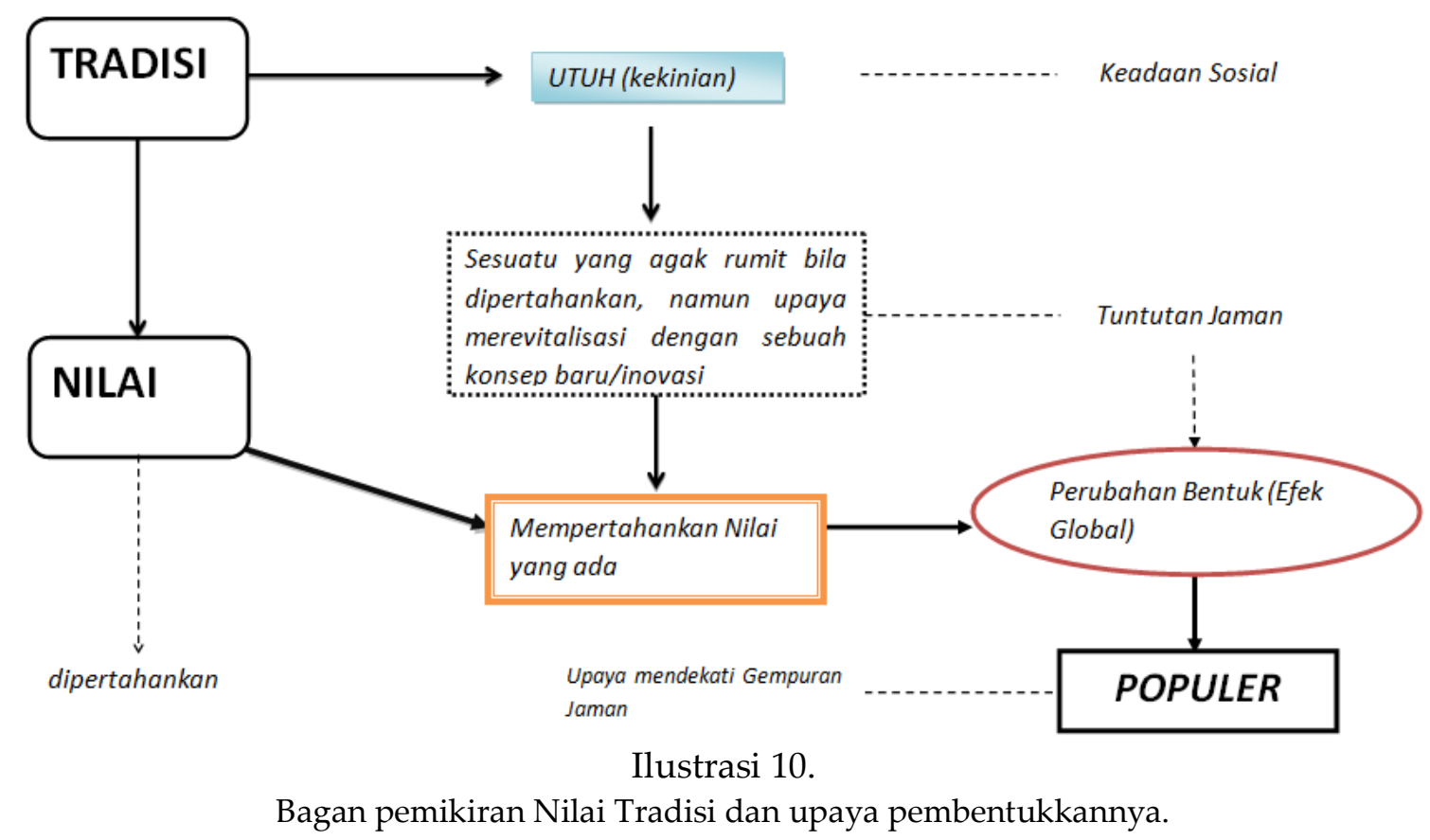

Nilai tradisi adalah suatu pandangan mengenai baik-buruk, indah-tidak indah dalam suatu konteks masyarakat dan diteruskan sebagai upaya mempertahankan dan melestarikan nilai-nilai dalam warisan budaya tertentu. Sehingga pilihan istilah populer dirasa dapat memberi peluang mendekati konteks masyarakat saat ini. Populer sendiri memiliki makna persinggungannya dengan masyarakat, yang diartikan sebagai sesuatu hal yang dikenali, dipahami, dilakukan, gaya hidup juga mengandung komersil.

NILAI TRADISI $\rightarrow$ MUSIK POPULER $\rightarrow$ WUJUD LAGU ANAK

Ilustrasi 11.

Rangkaian proses penciptaan lagu anak yang berangkat dari nilai tradisi.
Musik populer diyakini sebagai musik rakyat, masyarakat umum dalam segala konteksnya. Demikian juga keadaan anak-anak, perilaku mengikuti perkembangan jaman dengan kebiasaan masyarakat modern yang dekat dengan teknologi, tidak mampu kita hadang keberadaannya. Oleh karena itu sesuatu yang populer saat ini dan yang dikenal anak-anak dapat menjadi suatu landasan dalam mencipta.

Nilai tradisi harusnya dimaknai seperti nilai-nilai pada umumnya (nilai pengetahuan, nilai kerjasama, nilai gotong royong, nilai sosial, nilai moral dan lain sebagainya). Pemisahan terhadap dua konten kata tersebut menyebabkan pemisahan makna antara arti tradisi dan nilai, sehingga maksud dari nilai tradisi menjadi terlalu abstrak. Maka nilai tradisi yang dimaksud harus dipandang 
sebagai nilai-nilai yang memiliki kandungan tradisi, nilai dengan konten tradisi. Wujudnya dapat dilihat dalam karya-karya lagu yang umum kita dengar seperti lagu pop sunda karya Darso, dalam karyanya instrumentasi iringan yang digunakan menggunakan mayoritas instrumen Barat, hanya disisipi melodi aksen pentatonis yang mirip dengan Sunda. Maksudnya adalah pentatonis Sunda yang disebut sebagai laras pelog, madenda, slendro yang berbeda dengan nada petatonis Barat. Pentatonis Sunda yang mengikuti tata harmoni musik Barat sebetulnya tidak bisa dikatakan Sunda, tetapi mirip Sunda.

Menilai suatu karya seni yang memiliki nilai tradisi itu sendiri perlu dengan seksama ditilik kebenarannya. Berat ke Barat atau Berat ke Timur, yang dimaksud adalah konten konsep musik garap lagu tersebut yang dipengaruhi idiom-idiom musik baik Barat maupun Timur perlu kita bandingkan. Persentase tersebut dapat dilihat dari elemen-elemen pembentuk musik di atas. Dengan menilik idiom dalam elemen yang ada sesungguhnya dapat kita ambil keputusan memiliki nilai tradisi atau kurang memiliki nilai tradisi.

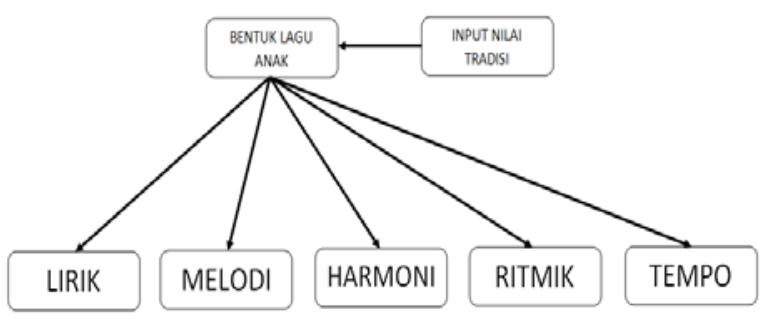

Ilustrasi 12

Bagan elemen lagu yang perlu disisipi nilai tradisi

Maksud bagan di atas adalah bagaimana input nilai tradisi dalam elemen pembentuk lagu anak diciptakan. Dalam idiom tradisional yang kental terasa adalah tangga nada pentatonisnya serta bahasa yang digunakan. Sehingga pemilihan lirik dapat menggunakan bahasa daerah etnik tertentu. Seperti lagu populer yang didendangkan
Yura dengan judul "Kataji", musik berkonsep broadway tetapi lirik menggunakan bahawa Sunda. Namun dalam karya lagu Yura tersebut tidak menggunakan tangganada pentatonis Sunda, sehingga nilai tradisi dalam lagu tersebut kurang tepat. Sehingga penggunaan melodi menggunakan laras pentatonis dirasa akan menambah nilai tradisi; Hal lain yang masih belum dikaitkan dalam pembahasan ini adalah kaitan karya lagu tersebut dengan bobot dan penikmatan rasa serta nuansa musik tradisinya, sehingga diperlukan kajian selanjutnya untuk dapat dilanjutkan. Pada segi harmoni, ritmik dan tempo disesuaikan dengan konsep musik populer pada umumnya; Harmoni dalam entitas Sunda jauh lebih kearah filosofis, ketimbang bunyi yang simetris. Sehingga untuk ritmik dan tempo dimasukkan ke dalam bentuk umum.

Berdasar apa yang dipaparkan di atas maka perlunya mencari hal yang dianggap penting dalam nilai tradisi tersebut. Suatu masyarakat tertentu yang memiliki kekuatan etnisnya merasa perlu memperhatikan segala sesuatu yang dimiliki dalam unsur kebudayaan tersebut agar tetap bertahan. Kebertahanan tersebut tentu merujuk juga pada identitas. Untuk membedakan satu dengan yang lain tentu dibutuhkan identitas.

\section{Penutup}

Berdasar hasil bedah bentuk musik, maka pengembangan atas penjabaran detail dari kriteria lagu anak sekaligus elemen penting penciptaan lagu anak dapat dilihat dari bentuk melodi, harmoni, tempo, penggunaan notasi, variasi motif, dan tema kalimat, maka pola penciptaan lagu anak secara umum memiliki:

- Lirik yang dibangun merupakan aktifitas anak dalam mendeskripsikan apa yang dilihat, dirasa dan dipikirkannya.

- Harmoni/akor yang sederhana, dengan memperhatikan alur kalimat dalam frase tanya dan jawab. Awal lagu pada birama 
pertama biasanya dimulai dengan akor I dan diakhiri akor $\mathrm{V}$.

- Tempo yang digunakan dalam membentuk lagu anak sekitar $70 \mathrm{~s} / \mathrm{d} .90 \mathrm{bpm}$.

- Penggunaan figur notasi balok antara not penuh, dua ketuk, satu ketuk, dan setengah ketuk.

- Bentuk melodi yang dibentuk melalui frase tanya dan jawab, serta tema yang dibentuk oleh satu dan maksimal dua bagian (satu bagian terdiri dari 8-16 birama).

- Pengembangan motif melodi melalui teknik diminusi dan augmentasi nilai not, repetisi motif, dan inversi.

Berdasar hasil di atas, diskusi, dan wawancara, maka di dapat model penciptaan lagu anak populer yang berangkat dari tradisi antara lain:

- Persentase antara dua idiom musik Barat ataupun Timur perlu dibandingkan dan dilihat berat sisi Barat atau Timurnya, agar yang disebut lagu yang memiliki nilai tradisi dapat diverifikasi.

- Wujud elemen dasar pembentuk musik merupakan elemen yang dapat diinisiasi dengan idiom musik tradisi.

- Pemahaman antara Nilai dan tradisi perlu ditinjau kembali, bahwa yang dimaksud nilai tradisi merupakan satu kesatuan, tidak dipisahkan. Sehingga penilaian tersebut mutlak pada nilai yang mengandung konten tradisi (unsur kebudayaan).

Garis besar model pembentukkannya adalah lirik (bahasa daerah), melodi (tangga nada pentatonis yang disesuaikan dengan harmoninya), harmoni (Barat yang memberi pembatasan), ritmik (umum baik Barat maupun tradisi), dan tempo (umum). Pengertian umum disini mengikuti kaidah musik populer pada umumnya.

\section{Referensi}

Appleby, Amy. 1995. You Can Write a Song. New York: Music Sales Corporation Campbell, Patricia Shehan. 1998. Songs In Their Heads: Music And Its Meaning in Children's Lives. New York: Oxford University Press.

Carneiro, Manuela. 2009. "Culture" and Culture: Traditional Knowledge and Intelectual Rights. Chicago: Prickly Paradigm Press

Cresswel, Jhon W. 1998. Qualitative Inquary dan Research Design: Choosing Among Five Traditional. USA: Sage Publication, Inc

Djelantik. 1990. Pengantar Dasar Ilmu Estetika Jilid 1: Estetika Instrumental. Denpasar: STSI Denpasar

Gea, Antonius Atosokhi, Antonina Panca Yuni Wulandari \& Yohanes Babiramai. 2005. Relasi Dengan Sesama. Jakarta: PT. Gramedia.

Lydon, Michael. 2004. Song Writing Success: How to Write Songs for Fun and (Maybe) Profit. London: Routledge.

Mardalis. 2010. Metode Penelitian Suatu Pendekatan Proposal. Jakarta: Bumi Aksara.

Marsh, Kathryn. 2008. The Musical Playground: Global Tradition and Change in Children's Songs and Games. USA: Oxford University Press.

Mattulada. 1997. Kebudyaan Kemanusiaan dan Lingkungan Hidup. Makasar: Hasanuddin University Press.

Maulana, M.Lutfi Syifa. 2014. “Tradisi Bantengan dan Modernisasi (Studi Eksistensi Tradisi Bantengan di Dusun Banong Desa Gerbangsari Kecamatan Jtirejo Kabupaten Mojokerto)". Skripsi Prodi Sosiologi Fakultas dakwah dan Imu Komunikasi Universitas Islam Negeri Sunan Ampel Surabaya.

Peursen, C.A. Van. 1988. Strategi Kebudayaan. Yogyakarta: Kanisius. 
Prier, Karl Edmund. 2013. Ilmu Bentuk Musik. Yogyakarta: Pusat Musik Liturgi.

Prier, Karl Edmund. 2014. Ilmu Harmoni. Yogyakarta: Pusat Musik Liturgi.

Sztompka, Piotr. 2007. Sosiologi Perubahan Sosial. Jakarta: Prenada Media Grup.

Sumardjo, Jacob. 2011. Sunda; Pola Rasionalitas Budaya. Bandung: Kelir.

Supriadi, Dedi. 1994. Kreativitas, Kebudayaan $\mathcal{E}$ Perkembangan Iptek. Bandung: Alfabeta

Yin, Robert K. 2012. Studi Kasus: Design dan Metode. Jakarta: Rajawali Pers. 